substances is needed, but this example of a complementary action suggests a new line of attack in both chromosome ana cancer research.

John Innes Horticultural Institution,

P. T. Thomas.

R. DREW.

Merton, London, S.W.19.

Oct. 8 .

1 Shmuck, A., and Gusseva, A., C.R. Acad. Sci U.R.S.S., 29, 316 (1940).

${ }^{2}$ Levan, A., and Ostergren, G., Hereditas, 29, 381 (1943).

'Patton, R. L., and Nebel, B. R., Amer. J. Bot., 27, 609 (1940).

‘ Davis, W. W., and Parker, T. U., J. Amer. Chem. Soc., 64, 101 (1942).

Lisle, E. B., J. Soc. Chem. Ind., 61, 148 (1942).

\section{Relapsing Fever and B. proteus X Kingsbury}

WHILE in Ethiopia with a mobile bacteriological laboratory, it was noted that there was an association between the findings of blood spirochates and an agglutination of $B$. proteus $X$ Kingsbury. Of 650 cases in which Borrelia were found and which were tested for agglutinations, 211 gave agglutination of Kingsbury in dilutions of $1 / 100$ and more. An examination of specimens submitted for Kahn test failed to reveal a corresponding high level in 'normal' individuals, and the testing of malaria cases disposed of the possibility of an 'anamnestic' type of reaction.

A series of 110 cases in which spirochætes were found was followed up with agglutination reactions every fourth day. These cases were for the most part under arsenical treatment. Some had relapses and some died. Their responses to $B$. proteus $X$ Kingsbury were as follows:

\begin{tabular}{|l|c|c|}
\hline \multirow{2}{*}{ Clinical course } & \multicolumn{2}{|c|}{ Agglutination of Kingsbury in 1/100 } \\
\cline { 2 - 3 } & Positive & Negative \\
\hline No relapse & 6 & 35 \\
One or more relapses & 22 & 27 \\
Deaths & - & 20 \\
\hline
\end{tabular}

In those relapsing cases which responded there was a progressive rise of titre, in one case reaching $1 / 6400$. Immediately after what was to prove the last relapse there was a rapid fall in titre; and a month after it had completely disappeared, that is, less than $1 / 50$.

We had cases showing agglutinations in. which spirochætes were never demonstrated. Some of these were treated empirically as relapsing fever, and recovered, but some others gave a 'typhus' picture.

These cases were all in the highlands where Ornithoiorus is unknown, and judging by the parallelism with epidemic typhus were probably louseborne.

Unfortunately, the exigencies of the Service did not permit of further investigation.

Springfield Military Hospital,

R. Elsdon-Dew.

Durban, Natal. Sept. 28.

\section{Glycogen in Adipose Tissue after Insulin Injection}

WHEN insulin is injected into a normal rat of about 100 gm. maintained on an ordinary diet, a transient appearance of glycogen is demonstrable in the adipose tissue. If, after the glycogen has disappeared, the insulin injection is repeated, new transient deposition of adipose glycogen is induced. It should be added that different types of adipose tissue differ quantitatively from one another in ability to store glycogen following insulin treatment. In general, deposition occurs most rapidly in the brown interscapulary adipose, less rapidly in mesenterial adipose, and least rapidly in other adipose stores. Seasonal fluctuations, too, are of importance. In summer, the demonstration of deposition necessitates no particular precautions; in winter, deposition occurs less rapidly and then only if the animals are maintained above $21^{\circ} \mathrm{C}$. On a diet of high calorific value, and if relatively large doses of insulin are administered. Protamin-zinc-insulin is of greater effectivity than ordinary insulin. The adipose tissue of rablits is less active ${ }^{1}$. The effect of insulin in this animal is smaller and only detectable after sugar feeding.

Representative experiments which illustrate the above effects are given in Table 1 .

TABLE 1.

\begin{tabular}{|c|c|c|c|c|c|c|c|}
\hline \multirow[b]{2}{*}{ Month } & \multirow[b]{2}{*}{$\begin{array}{c}\text { Prot.-Zn.- } \\
\text { Insulin }\end{array}$} & \multirow{2}{*}{$\begin{array}{l}\text { Dura- } \\
\text { tion } \\
\text { of } \\
\exp \text {. } \\
\text { (hr.) }\end{array}$} & \multicolumn{3}{|c|}{$\begin{array}{l}\text { Glycogen gm./100 gm. } \\
\text { adipose tissue }\end{array}$} & \multirow[b]{2}{*}{$\begin{array}{l}\text { Blood } \\
\text { sugar }\end{array}$} & \multirow[b]{2}{*}{$\begin{array}{l}\text { No. } \\
\text { of } \\
\text { expts. }\end{array}$} \\
\hline & & & $\begin{array}{l}\text { In- } \\
\text { tersc. } \\
\text { fat }\end{array}$ & $\begin{array}{l}\text { Mesent. } \\
\text { fat }\end{array}$ & $\begin{array}{l}\text { Total } \\
\text { fat }\end{array}$ & & \\
\hline $\begin{array}{l}\text { March/ } \\
\text { April } \\
\text { Feb. }\end{array}$ & $\begin{array}{l}2 \times 1 \text { unit } \\
2 \times 3 \text { units } \\
\text { Controls }\end{array}$ & $\begin{array}{l}7 \\
7 \\
7\end{array}$ & $\begin{array}{l}0 \cdot 30 \\
0.29 \\
0.03\end{array}$ & $\begin{array}{l}0 \cdot 15 \\
0 \cdot 12 \\
0\end{array}$ & $\begin{array}{l}0 \cdot 052 \\
0 \cdot 045 \\
0\end{array}$ & $\begin{array}{r}74 \\
62 \\
118\end{array}$ & $\begin{array}{l}10 \\
19 \\
15\end{array}$ \\
\hline \multicolumn{8}{|c|}{ 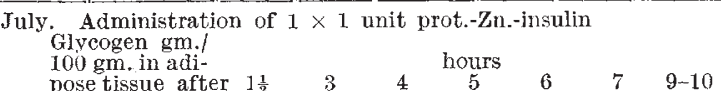 } \\
\hline $\begin{array}{l}\text { Interso } \\
\text { Mesent } \\
\text { Total } \mathrm{f}\end{array}$ & $\begin{array}{l}\text { ap. fat } \\
\text { fat } \\
\text { at }\end{array}$ & $0 \cdot 19$ & $0 \cdot 14$ & $\begin{array}{ll}0 \cdot 16 & 0 \\
0 \cdot 05 & 0 \\
& 0\end{array}$ & $\begin{array}{ll}21 & 0 \cdot 2 \\
\cdot 12 & 0 \cdot 1 \\
.04 & 0 \cdot 0\end{array}$ & $\begin{array}{ll}28 & 0 \cdot 40 \\
14 & 0 \cdot 15 \\
04 & 0 \cdot 07\end{array}$ & $\begin{array}{l}0 \cdot 08 \\
0 \cdot 04 \\
0\end{array}$ \\
\hline
\end{tabular}

Each value quoted represents the average of at least four experiments. Controls in seven random tests showed no glycogen in adipose ments.

Glycogen deposition always occurs in adipose tissue when fat synthesis from carbohydrates is taking place, for example, following intake of a carbohydrate-rich meal after a period of fasting ${ }^{1}$, following carbohydrate abundance without previous fasting or when animals are subjected to alternate periods of hunger and feeding as in the experiments of Mackay and Drury ${ }^{2}$. The occurrence of stable fat deposition in man following prolonged insulin treatment has long been $\mathrm{known}^{3}$. Mackay and collaborators ${ }^{4}$ have carried out a precise study of this effect in rats. It seems justifiable, therefore, to assurne that the glycogen deposition in adipose tissue following injection of insulin is merely a preliminary of fat deposition.

The observation has repeatedly been stressed that the insulin effect is associated with stimulation of appetite for carbohydrates and consequent increase in the earbohydrate intake. It was of importance accordingly to ascertain whether the deposition of glycogen in adipose tissue following insulin administration is secondarily induced and a result of in. creased carbohydrate intake, or a primary effect of the direct action of insulin on the adipose. The following experiments seem to support the latter explanation alternative: (1) In summer experiments, glycogen deposition in interscapulary adipose is already demonstrable within one hour of insulin injection. (2) Glycogen deposition in adipose tissue occurs rapidly following insulin injection also in rats maintained on a protein-high diet (70 per cent casein, 